\title{
Validation and Vitamin C Testing in Crystal Guava (Psidium guajava L.) With Variations of Origin With the HPLC Method (High Performance Liquid Chromatography)
}

\author{
Any Guntarti ${ }^{1}$, Endah Nurvita Hutami ${ }^{1}$ \\ ${ }^{1}$ Faculty of Pharmacy, Universitas Ahmad Dahlan, Jl. Prof. Dr. Soepomo, Janturan, Yogyakarta, Indonesia. \\ E-mail: any_guntarti@yahoo.co.id \\ Correspondence: Any Guntarti, Faculty of Pharmacy, Universitas Ahmad Dahlan, Jl. Prof. Dr. Soepomo, Janturan, \\ Yogyakarta, Indonesia.
}

Received: January 26, 2019 Accepted: February 21, 2019 Online Published: April 1, 2019

doi:10.5539/ijc.v11n1p52

URL: https://doi.org/10.5539/ijc.v11n1p52

\begin{abstract}
Crystal guava contains high vitamin C. Vitamin C is contained in different fruits, one of the factors is the altitude of the fruit plant growing areas. This study aims to determine the level of vitamin $\mathrm{C}$ in the slurry of crystal guava flesh with variations of origin using the HPLC method. Samples of crystal guava are obtained from the city of Bogor, Malang, and Gunung Kidul. The samples to be analyzed are prepared as a slurry. Qualitative analysis is done by identification using $\mathrm{KMnO}_{4}$ p.a, $\mathrm{FeCl}_{3}$ p.a, $\mathrm{AgNO}_{3}$ p.a as well as comparing the retention time of the sample with vitamin C. Method validation for system suitability, linearity and precision provide results that are eligible according to the applicable regulations. Quantitative analysis using HPLC with $\mathrm{C}_{18}$ stationary phase, water: methanol mobile phase (95: 5) v/v, flow rate of $1 \mathrm{~mL} / \mathrm{min}$, and run time of 7.5 minutes. Qualitative analysis by using $\mathrm{KMnO}_{4}, \mathrm{FeCl}_{3}, \mathrm{AgNO}_{3}$, and retention time (tR) shows positive results of the vitamin $\mathrm{C}$ existence. The average levels of vitamin $\mathrm{C}$ from Bogor, Malang, and Gunung Kidul, equal to $(0.4139 \pm 0.004) \mathrm{mg} / \mathrm{mL} ;(0.6746 \pm 0.03) \mathrm{mg} / \mathrm{mL}$; and $0.8608 \pm 0.002 \mathrm{mg} / \mathrm{mL}$ respectively.
\end{abstract}

Keywords: guava crystal, Gunungkidul, HPLC, origin, vitamin C

\section{Introduction}

People become aware of health and starting back to nature lifestyle. One attempt to maintain health is by eating fresh fruits. This has an impact on increasing the consumption of fruit in society. Indonesia is known as a country that has a variety of fruits especially tropical fruits. An example of fruit which is often found in the tropics is the guava fruit. Guava fruit has the scientific name of Psidium guajava. There are many variaties of guava fruit and one of them is the crystal guava. Crystal guava is a mutation of Bangkok guava found in 1991 in Taiwan. Crystal guava has a crunchy texture, sweet taste, and few seeds that become the society's favorite as a fresh-eaten fruit (Hadiati and Apriyanti, 2015).

Crystal guava contains vitamins (A, B1, and C), minerals, carbohydrates, water, proteins, lipids, and fiber (Lubis et al., 2017). Crystal guava can be used to increase antioxidants. Antioxidants are compounds that play an important role in protection from free radicals that come from the metabolic processes in the body or that enters the body from outside. One of the antioxidants contained in crystal guava fruit is vitamin C (Andarwulan et al., 2012).

Vitamin $\mathrm{C}$ is the most simple vitamin, easy to change due to oxidation, but very useful for humans. Vitamin $\mathrm{C}$ is easily damaged when it's in solution form due to oxidation by oxygen. Factors that can accelerate the oxidation are high temperature (Paul \& Ghosh, 2012; El-Ishaq \& Ebirinakem, 2015), acidity (Hacisevki, 20009), and storage time (Steskova et. al., 2006; Cvetkovic \& Jokanovic, 2009; Zhang et. al., 2016). Vitamin C found in fruits may be influenced by the type of fruit (Tareen et. al., 2015), site conditions (Abanto-Rodriguez et. al., 2016), climatic conditions before harvest time (Kaleem et. al., 2016), fruit maturity level (Lee \& Kader, 2000).

The amount of vitamin C content using High Performance Liquid Chromatography (HPLC). HPLC is the fastest developing analytical method. A good method needs a method validation test. Validation test includes system suitability, linearity, precision. This study aims to test the validity of the HPLC method and the determination of vitamin C levels based on the difference in origin of growing regions. The origin areas of guava crystals used are the city of Bogor, Malang and Gunung Kidul. 


\section{Research Methods}

Ingredients: crystal guava (Psidium guajava L.) varieties, standard vitamin C with $99 \%$ purity (E-Merck), aquabidest of HPLC grade (Ika Farma), methanol of HPLC grade (E-Merck), $\mathrm{KMnO}_{4}$ pro analysis (E-Merck), $\mathrm{FeCl}_{3}$ pro analysis. (E-Merck), $\mathrm{AgNO}_{3}$ pro analysis (E-Merck).

Equipments: glassware, a set of HPLC (LC-20AT with SPD-20A SHIMADZU detector), analytical scale (Ohaus of PA214 type), centrifuged (Eickmeyer), sonicator (Elmasonic), juicer (Sapporo), micropipette (Socorex), blue tip, $1 \mathrm{~mL}$ syringe, millipore PVDF of $0.22 \mu \mathrm{m}$ filter (Sartoriusstedim), filter paper no. 1 and no. 42 (Whatman).

Study course:

Slurry making: Crystal guava is washed with running water and drained. Crystal guava is separated between the skin, pulp, and seeds, then the flesh of fruit is smoothed using juicer (Safqatullah, et al, 2013).

Qualitative Analysis: performed with $\mathrm{FeCl}_{3}$ reagent, $\mathrm{KMnO}_{4}$ reagent, $\mathrm{AgNO}_{3}$ reagent, sample retention time.

Validation Methods include: System suitability test, Linearity, and Precision (Alvi and Hammami, 2011).

Quantitative analysis include:

Sample Preparation: Crystal guava of each region are taken in 5 pieces for analysis. The flesh of fruit that has been cleaned then is smoothed (slurry) using a juicer. Once the fruit is made into a slurry then weighed 10 grams of it carefully, then put it in a $10 \mathrm{~mL}$ flask and add aquabidest up to the mark. Next, it's centrifuged at a speed of $5000 \mathrm{rpm}$ for 5 minutes. The obtained supernatant is then filtered using a filter paper (Whatman no. 42) (Teepoo et al., 2012).

Determination of vitamin C: Clear samples are drawn as many as $100 \mathrm{uL}$ then put in a $10 \mathrm{~mL}$ flask, aquabidest is then added up to the mark. Millipore paper of $0.22 \mu \mathrm{m}$ filter is used to filter the samples. Samples of $20 \mathrm{~mL}$ are injected into the HPLC system (Kumar, et al., 2011).

Data Analysis: Levels of vitamin C in each sample of guava crystals of Margajaya (Bogor), Junrejo (Malang), and Nglipar (Gunung Kidul) is calculated by entering the AUC (Area Under Curva) values of vitamin C in the sample as a function of " $y$ " of the regression line of $y=b x+a$, where $x$ is the standard concentration on making the standard curve and $y$ is the absorbance of the standard solution of vitamin $\mathrm{C}$.

\section{Results and Discussion}

\section{Qualitative analysis}

Results of the qualitative analysis with $\mathrm{FeCl}_{3}$ reagent, $\mathrm{KMnO}_{4}$ reagent, and $\mathrm{AgNO}_{3}$ reagent shows positive results containing vitamin $\mathrm{C}$ for all the crystal guavas of Bogor, Malang and Gunung Kidul. Test with Ferric chloride reagent $\left(\mathrm{FeCl}_{3}\right)$ is one of the compounds that can be reduced. In this reaction, vitamin $\mathrm{C}$ serves as a reductant. Ferric chloride is reduced by vitamin $\mathrm{C}$ so that the yellow color of the ferric ions $\left(\mathrm{Fe}^{3+}\right)$ turn into colorless $\left(\mathrm{Fe}^{2+}\right)$. Vitamin $\mathrm{C}$ is oxidized by ferric ions $\left(\mathrm{Fe}^{3+}\right)$ into dehydroascorbic acid (Erina, et al. 2015).

The qualitative test results of slurry with $\mathrm{FeCl}_{3}$ reagent formed a yellow color that quickly disappears. It can be concluded that the slurry of crystal guavas contain vitamin C (Shishir et. al., 2014).

Potassium permanganate will oxidize vitamin $\mathrm{C}$, the reaction results will lead to the purple color of the permanganate ion $\left(\mathrm{MnO}_{4}\right)$ to colorless $\left(\mathrm{Mn}^{2+}\right)$. Meanwhile, vitamin $\mathrm{C}$ is oxidized by permanganate ion into dehydroascorbic acid (Azmat et al., 2012). The reaction with $\mathrm{KMnO}_{4}$ solution can be seen in Figure 1.

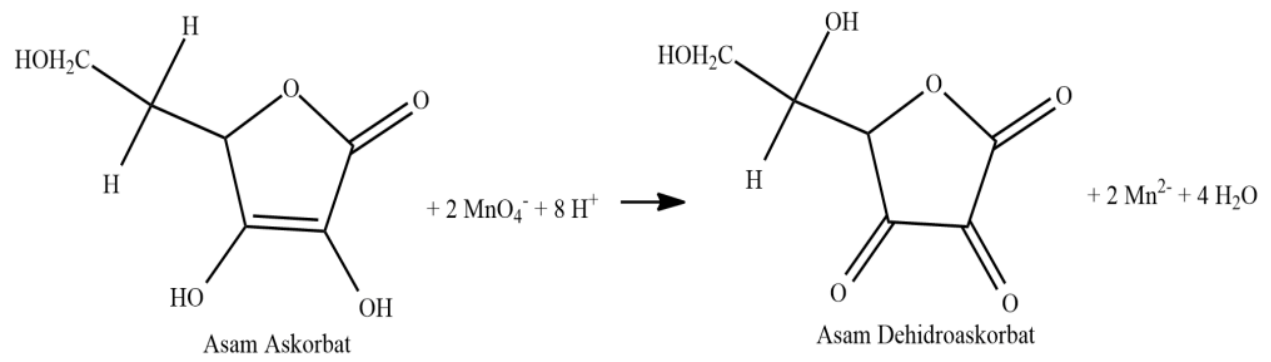

Figure 1. Vitamin C reaction with $\mathrm{KmnO}_{4}($ Svehla, 1985)

$\mathrm{AgNO}_{3}$ is a metal compound that can be reduced. In this reaction, vitamin $\mathrm{C}$ is as a substance which undergoes oxidation. $\mathrm{AgNO}_{3}$ is reduced by vitamin $\mathrm{C}$ so that the silver ions $\left(\mathrm{Ag}^{+}\right)$will lose the charge into $\mathrm{Ag}$ that can form a black color precipitate. Vitamin $\mathrm{C}$ which is oxidized by silver ions $\left(\mathrm{Ag}^{+}\right)$into dehydroascorbic acid (Chairam, et al. 2011). The reaction can be observed in Figure 2. 


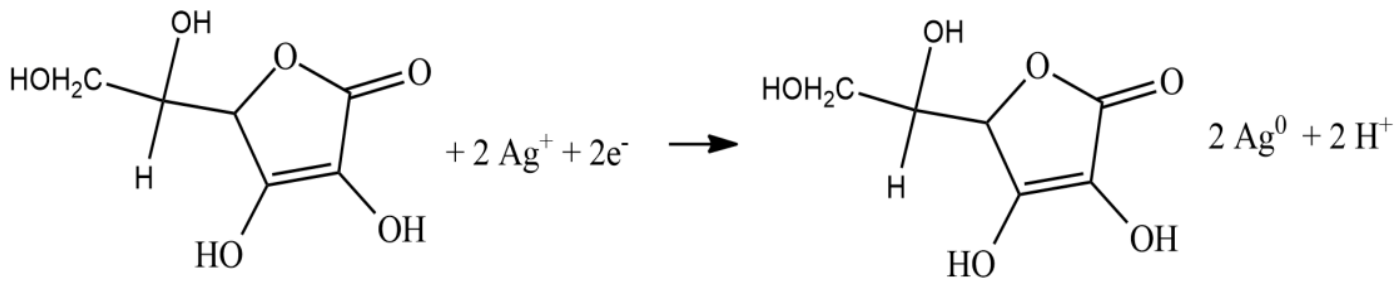

Figure 2. Vitamin $\mathrm{C}$ reaction with $\mathrm{AgNO}_{3}$ (Svehla, 1985)

The qualitative test results on the slurry with silver nitrate forms a black ash color solution which settles as time goes on.This happens because the oxidation reaction between vitamin $\mathrm{C}$ which is a strong reducing agent with $\mathrm{Ag}^{+}$is a metal so that reduction occurs quickly (Songsasen and Poowanathai, 2002). The potential of silver ions $\left(\mathrm{Ag}^{+}\right)$reduced by the samples are indicated by the change of color into black ash. Table I presents the examples of qualitative reactions of crystal guavas of Bogor.

Table I. Examples of Vitamin $\mathrm{C}$ test results with $\mathrm{FeCl}_{3}, \mathrm{KMnO}_{4}$, dan $\mathrm{AgNO}_{3}$ on crystal guavas of Bogor

\begin{tabular}{|c|c|c|c|}
\hline \multirow{2}{*}{ Sample } & \multicolumn{2}{|c|}{ Figure } & \multirow{2}{*}{ Result } \\
\hline & Before & After & \\
\hline \multicolumn{4}{|c|}{$\mathrm{FeCl}_{3}$} \\
\hline Standard & & & + \\
\hline Bogor & & & + \\
\hline
\end{tabular}

$\mathrm{KMnO}_{4}$ reagent

\begin{tabular}{lll}
\hline Standard & & + \\
\hline Bogor & & + \\
\hline
\end{tabular}

$\mathrm{AgNO}_{3}$ reagent

Standard
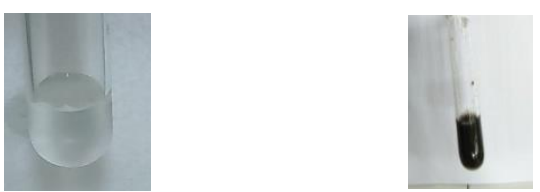

Bogor
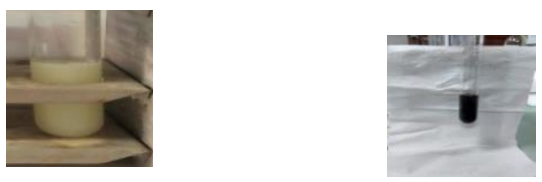

$+$ 
In addition to the test tube, a qualitative analysis using retention times obtained between vitamin $\mathrm{C}$ with standard samples of crystal guavas of Bogor, Malang, and Gunung Kidul (Figure 3).

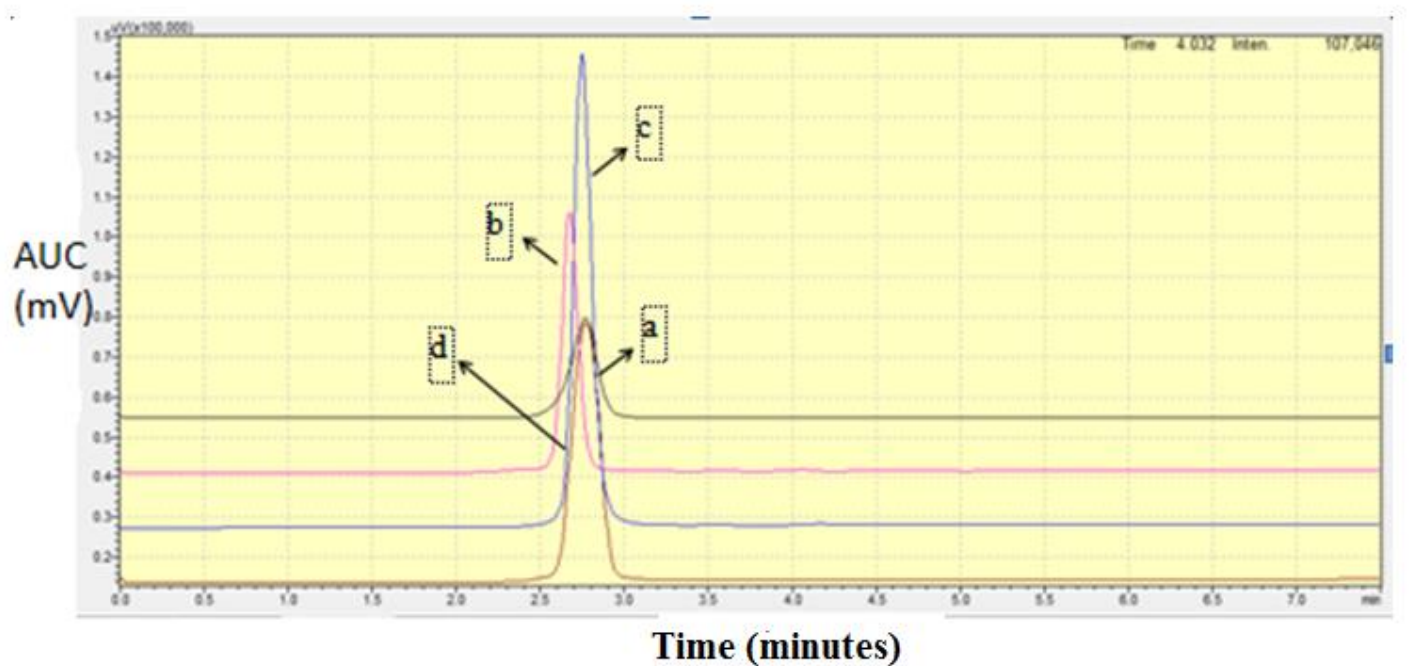

Figure 3. Chromatogram a) Standard Vitamin C b) Sampels from Bogor c) Sampels from Malang d) Samples from Gunung Kidul with FG metanol:aquabidest (5:95) v/v, FD $\mathrm{C}_{18}, \lambda 265 \mathrm{~nm}$, run time of 7,5 minutes, flow rate of $1 \mathrm{~mL} /$ minute.

Based on Figure 3, the obtained average value of $t_{R}$ on a standard vitamin $C$ is 2.621 minutes, an average $t_{R}$ value of fruit samples coming from Bogor, Malang, Gunung Kidul are 2.622 minutes, 2.673 minutes, and 2.578 minutes respectively. Based on these data, the value $t_{R}$ owned by the standard vitamin $C$ and the samples are relatively the same. It can be concluded that the sample of slurry contains vitamin C.

\section{HPLC Method Validation}

\section{System Suitability Test}

System suitability test is conducted to determine the start of the used tools, methods, and HPLC systems can give good results in the analysis process or not. System suitability test results are shown in Table II.

Table II. System Suitability Parameters

\begin{tabular}{ccccc}
\multicolumn{6}{l}{ Table II. System Suitability Parameters } \\
\cline { 2 - 6 } Replication & $\begin{array}{c}\text { Retention Time }\left(\mathrm{t}_{\mathrm{R}}\right) \\
(\text { minute) }\end{array}$ & $\begin{array}{c}\text { AUC } \\
(\mathrm{mV})\end{array}$ & Tailing Factor & $\mathrm{N}$ \\
\hline 1 & 2.627 & 1479079 & 0.980 & 2134.441 \\
2 & 2.668 & 1499691 & 1.031 & 2240.654 \\
3 & 2.596 & 1533179 & 0.940 & 2016.839 \\
4 & 2.563 & 1467415 & 0.903 & 2010.040 \\
5 & 2.543 & 1502495 & 0.885 & 1942.284 \\
6 & 2.543 & 1491676 & 0.877 & 1943.252 \\
\hline Average of & 2.590 & 1495589 & 0.936 & 2.048 \\
CV $(\%)$ & 1.94 & 1.523 & 0.644 & 5.74 \\
\hline References of CV & 5 & 5 & 15 & 15 \\
\hline
\end{tabular}

\section{AUC (Area Under Curve)}

Based on the table, it can be known that the factors of analytes separation with the HPLC method are the retention time, AUC, tailing factor, and theoritical plate $(\mathrm{N})$. The obtained results from several parameters indicate that the CV value of the retention time is $1.94 \%<2 \%$ and for the $\mathrm{CV}$ value of the AUC is $1.523 \%<5 \%$. The average value for the tailing factor is $0.644<15 \%$ and the value of $\mathrm{N}$ is $5.7 \%<15 \%$ (Ganjar and Rohman, 2007). From these results, it can be concluded that the HPLC method has good system suitability.

\section{Linearity}

Linearity is parameters of analytical method validation used to obtain the proportional results to the analyte concentration. Results of the linearity test can be seen in Table III. 
Table III. Relation of the standard concentration of vitamin C solution with AUC

\begin{tabular}{cccccc}
\hline No. & $\begin{array}{c}\text { Rate } \\
(\mu \mathrm{g} / \mathrm{mL})\end{array}$ & $\begin{array}{c}\text { AUC } \\
(\mathrm{mV})\end{array}$ & Linear Regression & R count & R theory \\
\hline 1 & 1 & 201617 & & & \\
2 & 3 & 289877 & & & \\
3 & 5 & 571615 & $y=106053.1 x+431039$ & 0.9911 & 0.9911 \\
4 & 7 & 793137 & & & \\
5 & 9 & 1010572 & & & \\
\hline
\end{tabular}

A correlation coefficient or the $\mathrm{R}$ value indicates that the linearity level of the relation between vitamin $\mathrm{C}$ levels with AUC area. From the table, the linear regression equation of $y=106053.1 x+431039$ with $\mathrm{R}$ values is calculated at 0.9911 . $\mathrm{R}$ value is a correlation coefficient that indicates the linearity level of relation between the analyte concentration and the peak area (Sugihartini et al, 2014). The obtained $\mathrm{R}$ value is at 0.9911 , whereas according to AOAC (2013), the suggested correlation coefficient is $\geq 0.99$. That result fulfills linearity requirements and demonstrates that the test with the HPLC method has good linearity, therefore the linear regression equation can be used to determine levels of vitamin C in the samples (Alvi and Hammami 2011).

\section{Precision}

Precision is a value that indicates the closeness of the analysis results that can be accepted. Precision is expressed as standard deviation or coefficient of variation. Careful analysis methods will provide fixed measurement results at any time from the same sample. The precision results are presented in Table IV.

Table IV. Standard Vitamin C Precision Test Data

\begin{tabular}{cccl}
\hline Rate $(\boldsymbol{\mu g} / \mathbf{m L})$ & AUC $(\mathbf{m V})$ & \multicolumn{2}{c}{ Parameter } \\
\hline \multirow{2}{*}{1} & 200151 & Mean & $: 197220.3$ \\
& 196674 & SD & $: 2699.29$ \\
& 194836 & CV & $: 1.37 \%$ \\
& 551378 & Mean & $: 544876.7$ \\
5 & 555964 & SD & $: 15403.85$ \\
& 527288 & CV & $: 2.83 \%$ \\
& 1011207 & Mean & $: 10000526$ \\
9 & 995184 & SD $: 9250.31$ \\
& 995186 & CV & $: 0.93 \%$
\end{tabular}

Based on the calculations in Table IV, CV values obtained at levels of $1 \mathrm{mg} / \mathrm{mL}$ of $1.37 \%$; levels of $5 \mathrm{mg} / \mathrm{mL}$ of $2.83 \%$; and levels of $9 \mathrm{mg} / \mathrm{mL}$ of $0.93 \%$. The method is stated accurately if the results of $\mathrm{CV}$ is $<5 \%$. These results indicate that this method qualifies precision requirements (Anonymous, 2001).

\section{Quantitative Analysis}

This method is chosen because it has high selectivity and sensitivity, and faster process. (Wardani, 2012). The linear regression equation obtained $y=106053.1 x+431039$ with the value of $\mathrm{R} 0.9911$. The results of the data analysis, the levels of vitamin C contained in the crystal guavas coming from Bogor amounted to $0.4139 \mathrm{mg} / \mathrm{mL}$; from Malang amounted to $0.6746 \mathrm{mg} / \mathrm{mL}$; and from South Mountain amounted to $0.8608 \mathrm{mg} / \mathrm{mL}$. Results of the calculation levels of vitamin $\mathrm{C}$ are shown in Table V. 
Table V. Calculation Levels of Vitamin C

\begin{tabular}{ccccc}
\hline Sample & $\begin{array}{c}\text { AUC } \\
(\mathrm{mV})\end{array}$ & $\begin{array}{c}\text { Rate } \\
(\mathrm{mg} / \mathrm{mL})\end{array}$ & $\begin{array}{c}\text { X } \pm \text { LE } \\
(\mathrm{mg} / \mathrm{g})\end{array}$ & $\begin{array}{c}\text { CV } \\
(\%)\end{array}$ \\
\hline BG1 & 481469 & 0.4133 & & \\
BG2 & 477000 & 0.4091 & & \\
BG3 & 474265 & 0.4065 & $0.4139 \pm 0.004$ & $1.52 \%$ \\
BG4 & 489142 & 0.4205 & & \\
BG5 & 488552 & 0.4200 & & \\
ML1 & 774336 & 0.6894 & & \\
ML2 & 779825 & 0.6946 & & \\
ML3 & 763558 & 0.6793 & $0.6746 \pm 0.03$ & \\
ML4 & 784125 & 0.6987 & & \\
ML5 & 744216 & 0.6109 & & \\
GK1 & 954859 & 0.8597 & & \\
GK2 & 951303 & 0.8563 & & \\
GK3 & 956909 & 0.8616 & $0.8608 \pm 0.002$ & $0.37 \%$ \\
GK4 & 960754 & 0.8616 & & \\
GK5 & 960712 & 0.8652 & & \\
\hline (Bogor); ML (Malang); GK (Gunung Kidul), LE=Limit of Error, CV= Correlation Coefficient
\end{tabular}

The highest levels of vitamin $\mathrm{C}$ is present in crystal guavas of Gunung Kidul. The lowest levels of vitamin $\mathrm{C}$ is present in crystal guavas of Bogor. This can happen because there are differences in the altitude of the crystal guavas planting areas. The collection sites of crystals guavas in Bogor has the altitude of $\pm 300 \mathrm{~m}$ above sea level, the Malang area of \pm $700 \mathrm{~m}$ above sea level, and Gunung Kidul area of $\pm 886 \mathrm{~m}$ above sea level. Therefore, the higher the altitude of the crystal guavas location planting, the higher the levels of vitamin $\mathrm{C}$ in crystal guavas. These results are in line with the research conducted by Fatchurrozak et al., (2013) which showed that fruit that grows in areas with an altitude of $1400 \pm$ 50 meters above sea level has vitamin $\mathrm{C}$ content of $11.94 \%$, an altitude of $1900 \pm 50$ meters above sea level is of $13.41 \%$, and an altitude of $2400 \pm 50$ meters above sea level is of $14.27 \%$. This is due to the higher altitude, the higher the environmental stress, for example, the lower the temperature, the higher the humidity, the less light intensity, which means the lighting duration is shorter. When plants are under stress, then the production of vitamin $\mathrm{C}$ increased. This is an attempt of plants to combat environmental stress (Fatchurrozak et al., 2013; Chandra and Sharma, 2013). Figure 4 presented the histogram acquisition of vitamin $\mathrm{C}$.

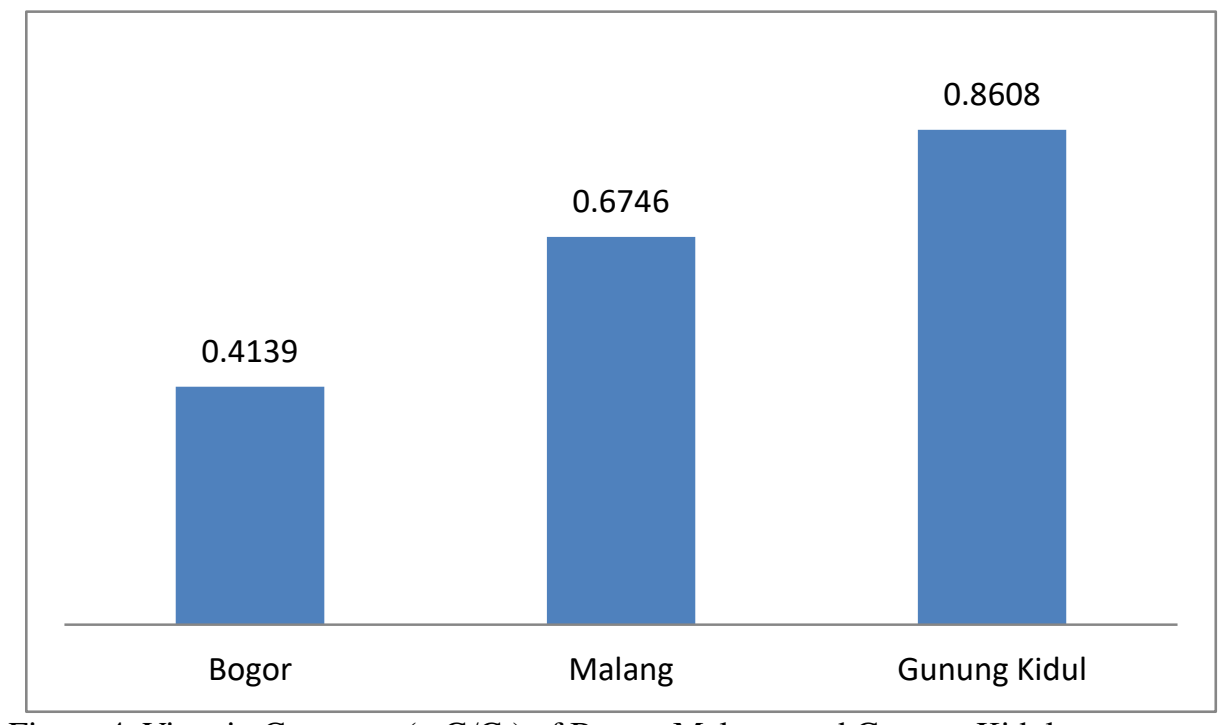

Figure 4. Vitamin C content (mG/G ) of Bogor, Malang, and Gunung Kidul

\section{Conclusion}

The results show that the crystal guavas of Bogor, Malang, and Gunung Kidul contain vitamin C. Method validation with system suitability test, linearity, and precision are in accordance with the provisions. Levels of vitamin C in crystal varieties of guava fruit from Margajaya (Bogor City), Bumiaji (Malang), and Nglipar (Gunung Kidul) are 0.4139 $\mathrm{mg} / \mathrm{mL} ; 0.6746 \mathrm{mg} / \mathrm{mL}$; and $0.8608 \mathrm{mg} / \mathrm{mL}$ respectively. 


\section{References}

Abanto-Rodriguez, C., Pinedo-Panduro, M., Alves-Chagas, E., Cardoso-Chagas, P., Tadashi-Sakazaki, P., de Menezes, P. H. S., Farias-Araujo, W., \& Murga-Orrilla, A. (2016). Relation between the mineral nutrients and the vitamin C content in camu-camu plants (Myrciria dubia) cultivated on high soils and flood soils of Ucayali, Peru. Scientia Agropecuaria, 7(3), 297-304. https://doi.org/10.17268/sci.agropecu.2016.03.18

Alvi, S. N., \& Hammami, M. M. (2011). Validated HPLC Method for Determination of Caffeine Level in Human Plasma using Synthetic Plasma: Aplication to Bioavailability Studies. Journal of Chromatographic Science, 292-296. https://doi.org/10.1093/chrsci/49.4.292

Andarwulan, N., Kurniasih, D., Apriady, R. A., Rahmat, H., Roto, A. V., \& Bolling, B. W. (2012). Polyphenols, Carotenoids, and Ascorbic Acid in Underutilized Medicinal Vegetables. Journal of Funcional Foods, 4, 339-347. https://doi.org/10.1016/j.jff.2012.01.003

Anonim. (2001). Guideance for Industry: Bioanalytical Method Validation. Food and Administration and Center for Drug Evaluation and Research, 25.

AOAC. (2013). Official Methods of Analysis of AOAC International. AOAC International.

Azmat, R., Naz, R., Qamar, N., \& Malik, I. (2012). Kinetics and Mechanisms of Oxidation of D-Fructose and D-Lactose by Permanganat Ion in an Acidic Medium. Natural Science, 4(7), 466-478. https://doi.org/10.4236/ns.2012.47063

Chairam, S., Sriraksa, W., Amatatongchai, M., \& Somsook, E. (2011). Electrocatalytic oxidation of ascorbic acid using a poly (aniline-co-m-ferrocenylaniline) modified glassy carbon electrode. Sensors, 11, 10116-10179. https://doi.org/10.3390/s111110166

Chandra, R., \& Sharma, K. D. (2013). Quantitative Determination of Paracetamol and Caffeine From Formulated Tablet by Reversed Phase-HPLC Separation Technique. International Journal of Chromatographic Science, 31-34.

Cvetkovic, B. R., \& Jokanovic, M. R. (2009). Effect of preservation method and storage condition on ascorbic acid loss in beverages. APTEFF, 40, 1-7. https://doi.org/10.2298/APT0940001C

El-Ishaq, A., \& Obirinakem, S. (2015). Effect of temperature and storage on vitamin C content in fruits juice. International Journal of Chemical and Biomolecular Science, 1(2), 17-21.

Fatchurrozak, Suranto, \& Sugiyarto. (2013). Pengaruh Ketinggian tempat Terhadap Kandungan Vitamin C dan Zat Antioksidan pada Buah Carica pubescens di Dataran Tinggi Dieng. EL-VIVO, 1(1), $24-31$.

Hacisevki, A. (2009). An overview of ascorbic acid biochemistry. J. Fac. Pharm. Ankara, 38(3), 233-255.

Jha, A. K., \& Prasad, K. (2010). Green Synthesis of Silver Nanoparticle Using Cyas Leaf. International Journal of Green Nanotechnology: Physics and Chemistry, 1, 110-117. https://doi.org/10.1080/19430871003684572

Kaleem, A., Nazir, H., Pervaiz, S., Iqtedar, M., Abdullah, R., Aftab, M., \& Naz, S. (2016). Investigation of the effect of temperature on vitamin $\mathrm{C}$ in fresh and packed fruit juices. FUUAST J. Biol., 6(1), 117-120.

Kumar, K. R., Kumar, P. P., \& Mallikarjuna, R. N. (2011). Development and Validation of RP_HPLC Method for The Estimation of Ascorbic Acid in Health Drink. Journal of Chemical and Pharmaceutical Reasearch, 363-374.

Lee, S. K., \& Kader, A. A. Preharvest and postharvest factors influencing vitamin C content of horticultural crops. Postharvest Biology and Technology, 20, 207-220.

Lubis, N., Prasetiawati, R., \& Septiani, W. (2017). Determination of Vitamin C Red Guava (Psidium guajava Linn.) Fruit Juice with Variation of Beverage Pacaging. International Journal of Advances in Science Engineering and Techology, 5(4), 51-55.

Paul, R., \& Ghosh, U. (2012). Effect of thermal treatment on ascorbic acid content of pomegranate juice. Indian Journal of Biotechnology, 11, 309-313.

Shafqatullah, Hussain, A., Ali, J., Khaliqurrehman, \& Asadullah. (2012). A Simple and Rapid HPLC Method for Analysis of Vitamin C in Local Packed Juices of Pakistan. Journal of Scientific Research, 12(8), 1085-1091.

Shishir, M. R. I., Taip, F. S., Aziz, N. A., \& Talib, R. A. (2014). Physical properties of spray-dried pink guava (Psidium guajava) powder. Agriculture and Agricultural Science Procedia, 2, 74-81. https://doi.org/10.1016/j.aaspro.2014.11.011

Songsasen, A., \& Poowanathai, N. (2002). Recovery of Silver as Silver Nitrate from Waste Silver Chloride in Quantitative Analysis Laboratory. Kasetsart J. (Nat. Sci.), 36, 435-330. 
Steskova, A., Morochovicova, M., \& Leskova, E. (2006). Vitamic C degradation during storage of fortified foods. Journal of Food and Nutrition Research, 45(2), 55-61.

Sugihartini, N., Fudholi, A., Pramono, S., \& Sismindari. (2014). Validation Methode of Quantitative Analysis of Epigallocathecin Gallat By High Performance. Pharmaciana, 4(2), 111-115.

Tareen, H., Mengal, F., Masood, Z., Mengal, R., Ahmed, S., Bibi, S., ... Nawaz, Z. (2015). Determination of vitamin C content in citrus fruits and non-citrus fruits by titrimetric method, with special reference to their nutritional importance in human diet. Biological Forum, 7(2), 367-369.

Zhang, J., Han, H., Xia, J., \& Gao, M. (2016). Degradation kinetics of vitamin C in orange and orange juice during storage. Advance Journal of Food Science and Technology, 12(10), 555-561.

https://doi.org/10.19026/ajfst.12.3303

\section{Copyrights}

Copyright for this article is retained by the author(s), with first publication rights granted to the journal.

This is an open-access article distributed under the terms and conditions of the Creative Commons Attribution license (http://creativecommons.org/licenses/by/4.0/). 